\title{
Law $\mathbf{X}$ Social Inquiry
}

Journal of the American Bar Foundation

Volume 19, Number 3, Summer 1994

The University of Chicago Press 


\section{Law \& \\ Social Inquiry}

Journal of the American Bar Foundation

Published by The University of Chicago Press

$\begin{array}{ll}\text { Editors } & \text { Arthur F. McEvoy } \\ & \text { Elizabeth Mertz } \\ & \text { Peter Siegelman } \\ \text { Review Editor } & \text { Howard S. Erlanger } \\ \text { Associate Editors } & \begin{array}{l}\text { Karyl A. Kinsey } \\ \text { Robert L. Nelson } \\ \text { Christopher L. Tomlins }\end{array} \\ & \text { John Atkinson } \\ \text { Managing Editor } & \text { Rozanne Caldwell } \\ \text { Editorial Coordinator } & \end{array}$

\section{Editorial Board}

Richard L. Abel, Professor of Law, University of California, Los Angeles

Ian Ayres, Professor of Law, Stanford University

Donald Black, Professor of Sociology, University of Virginia

Erhard Blankenburg, Professor of Sociology of Law, Free University of Amsterdam

John Braithwaite, Professor of Law and Sociology, The Australian National University

Jane F. Collier, Professor of Anthropology, Stanford University

Phoebe C. Ellsworth, Professor of Law and Psychology, University of Michigan

Eliot L. Freidson, Professor of Sociology, New York University

Lawrence M. Friedman, Professor of Law, Stanford University

Hazel Genn, Professor of Law, Queen Mary and Westfield College, University of London

Carol J. Greenhouse, Professor of Anthropology, Indiana University

Valerie P. Hans, Professor of Criminal Justice, University of Delaware

Earl Johnson, Jr., Associate Justice, California State Court of Appeal

Doreen McBarnet, Senior Research Fellow, Centre for Socio-Legal Studies, Wolfson College, Oxford

Carrie J. Menkel-Meadow, Professor of Law, University of California, Los Angeles

Laura Nader, Professor of Anthropology, University of California-Berkeley

Judith Resnik, Professor of Law, University of Southern California

Daniel Rubinfeld, Professor of Economics, University of California-Berkeley

Dietrich Rueschemeyer, Professor of Sociology, Brown University

Martin M. Shapiro, Professor of Law, University of California-Berkeley

Susan S. Silbey, Professor of Sociology, Wellesley College

David Sugarman, School of Law, Lancaster University

David M. Trubek, Professor of Law, University of Wisconsin

Barbara Yngvesson, Professor of Anthropology, Hampshire College

Michael Zander, Professor of Law, Department of Law, London School of Economics 


\section{Law $\&$}

\section{Social Inquiry}

Volume 19, Number 3, Summer 1994

\section{ARTICLES}

Genealogy and Jurisprudence: Nietzsche, Nihilism, and the Social

Scientification of Law

Marianne Constable

Commentaries

Passionate Kisses?

Kenneth Cmiel

Christine B. Harrington and John Brigham

Asking the Right Question

Frank Munger

Leading Law into the Abyss: What (If Anything) Has Sociology

Done to Law?

Austin Sarat

Rejoinder

Thinking Nonsociologically about Sociological Law Marianne Constable

"You Wouldn't Take a Seven-Year-Old and Ask Him All These

Questions": Jurors' Use of Practical Reasoning in Supporting Their

Arguments

John F. Manzo

\section{REVIEW ESSAYS}

Two Faces of Justice: A Milestone in Quantitative Cross-cultural Research

David T. Johnson and Setsuo Miyazawa

Interpretation and Validity Assessment in Qualitative Research: The

Case of H. W. Perry's Deciding to Decide

Herbert M. Kritzer

Shaky Grounds: The Case against the Case against Antidiscrimination Laws

Peter Siegelman

Heroic Medicine, Physician Autonomy, and Patient Rights

Lisa R. Staffen

Pragmatism and Faith: Selznick's Complex Commonwealth

David C. Williams

Religion, Law, and Contemporary American Culture: Carter and Powell

Booth Fowler 


\section{Publication Policy}

The American Bar Foundation is an independent research institute committed to socio-legal research. Consistent with its mandate to create and disseminate knowledge about law, the legal profession, and legal institutions, Law and Social Inquiry: Journal of the American Bar Foundation invites the submission of articles that make original contributions to understanding of socio-legal processes. Law and Social Inquiry publishes both empirical and theoretical studies from a variety of disciplinary perspectives. The analyses, conclusions, and opinions are those of the authors alone.

Manuscript Evaluation: Law and Social Inquiry is a refereed journal. Manuscripts that the Editors deem appropriate for the journal are evaluated by two or more reviewers with expertise in the relevant subject matter and methodology. Manuscripts produced by ABF research fellows are evaluated by the same process as outside manuscripts and are not accorded priority in publication.

Submission of Manuscripts: Manuscripts submitted to Law and Social Inquiry should be typed double-spaced and be accompanied by an abstract of not more than 150 words. The review process is anonymous; all identifying information should appear only on a separate cover sheet and not in the body of the manuscript.

Law and Social Inquiry does not accept multiply submitted articles. The Editors endeavor to make decisions promptly, usually about two months after submission.

Editing of Manuscripts: All manuscripts accepted for publication are edited for style by professional copyeditors in consultation with the author. Copyeditors do not check citations. Authors see edited manuscripts and/or proofs.

Reprints to Authors: Without charge, we provide authors with 25 reprints of their articles or essays or of the Symposium in which their contributions appear. Additional reprints may be ordered at the author's expense. Authors receive 1 copy of the issue in which their contributions appear.

Republication Rights: The Foundation normally permits authors to republish their manuscripts in books or use their manuscripts after publication, but Law and Social Inquiry has the right to first publication of edited manuscripts. The journal retains the right to republish manuscripts as reprints or as part of any reproduction of the issue or volume in which they appear, by any means, including without limit electronic means or microfilm.

Copying Beyond Fair Use: The code on the first page of a contribution in this journal indicates the copyright owner's consent that copies of the contribution may be made beyond those permitted by Sections 107 or 108 of the U.S. Copyright Law provided that copies are made only for personal or internal use, or for the personal or internal use of specific clients and provided that the copier pay the stated per-copy fee through the Copyright Clearance Center, Inc., 27 Congress Street, Salem, MA 01970. To request permission for other kinds of copying, such as copying for general distribution, for advertising or promotional purposes, for creating new collective works, or for resale, kindly write to the Permissions Department, University of Chicago Press, 5801 S. Ellis Avenue, Chicago, IL 60637. 
Comments and Responses: Comments on or responses to articles or review essays in the form of brief, scholarly statements will be published at the discretion of the Editors or Review Section Editor.

Send article manuscripts to:

The Editors

Law and Social Inquiry

American Bar Foundation

750 N. Lake Shore Drive

Chicago, IL 60611

(312) $988-6500$
Send inquiries regarding review essays to:

Howard S. Erlanger

Review Editor

Law and Social Inquiry

Institute for Legal Studies

Law School

University of Wisconsin

Madison, WI 53706

(608) 263-7405

Annual U.S. subscription rates:

$\begin{array}{llrr} & 1 \mathrm{yr} . & 2 \mathrm{yr} . & 3 \mathrm{yr} . \\ \text { Individuals } & \$ 36 & \$ 66.25 & \$ 91.80 \\ \text { Academic } & \$ 29 & \$ 53.35 & \$ 73.95 \\ \text { Institutions } & \$ 59 & \$ 108.55 & \$ 150.45\end{array}$

Outside U.S. please add a postage charge of $\$ 6.00$ per year to the U.S. rates. Canadians please add 7\% GST tax to above rates as follows: Oneyear rates: Individuals $\$ 2.52$; Academic $\$ 2.03$; Institutions $\$ 4.13$. Two-year rates: Individuals \$4.63; Academic \$3.73; Institutions \$7.59. Three-year rates: Individuals \$6.42; Academic \$5.17; Institutions \$10.53.

Single copies: $\$ 14.75$ for institutions, $\$ 9.00$ for individuals. Checks should be made payable to Law $\mathscr{E}$ Social Inquiry, University of Chicago Press, Journals Division, P.O. Box 37005, Chicago, Illinois 60637. (Fax: 312-7530811.) Volumes 1-12 available from Fred B. Rothman \& Company, 10368 West Centennial Road, Littleton, Colorado 80127. (303) 979-5657

Volumes available in microfilm from University Microfilms International, 300 North Zeeb Road, Ann Arbor, Michigan 48106.

(c) 1994 American Bar Foundation. All rights reserved.

Law and Social Inquiry: Journal of the American Bar Foundation (ISSN: 0897-6546) is published quarterly-winter, spring, summer, and fall-by The University of Chicago Press, 5720 South Woodlawn Ave., Chicago, Illinois 60637. Subscription agent for Japan: Kinokuniya Company, Ltd. Second-class postage paid at Chicago, Illinois and at additional mailing office.

POSTMASTER: Send address changes to: Law and Social Inquiry, P.O. Box 37005, Chicago, IL 60637. 